\title{
Response of starter broilers to diets containing graded levels of rice bran with or without palm oil
}

\author{
Ibiyo, L. M. O. and Atteh, J. O. ${ }^{1}$ \\ National Institute of Freshwater Fisheries Research, New Bussa, Niger State, Nigeria. \\ 'Department of Animal Production. Faculty of Agriculture, University of Ilorin,Ilorin, Nigeria
}

\begin{abstract}
One hundred and forty four (144) day-old broiler chicks of hubbard breed from a commercial hatchery were used to investigate the response of broiler chicks to 0,10 and 20\% dietary rice bran with or without 5\% supplementary palm oil in a 5 week feeding trial. Significant interaction between dietary levels of rice bran and palm oil were observed on feed intake, weight gain and feed/gain ratio $(P<0.05)$. Increase in dietary levels of rice bran reduced feed transit time in the GIT $(P<0.05)$ while supplementary palm oil had the opposite effect $(P<0.05)$. There was decrease in protein, fat and fibre retention with increase in dietary levels of rice bran $(P<0.05)$. There was a tendency for dietary supplementation of palm oil to increase protein and fat retention $(P<0.05)$ but had no significant effect on crude fibre retention $(P>0.05)$. It was concluded that broiler chicks could tolerate up to $10 \%$ dietary levels of rice bran without detrimental effects on performance and nutrient retention. With supplementary 5\% palm oil added to such a diet, performance was comparable to that of birds fed a standard diet with money saved in the process.
\end{abstract}

Key words:- Broiler, Rice bran, Palm oil, Performance, Nutrient retention.

\section{Introduction}

The cost of poultry feed has been on the increase in recent times and it forms the largest percentage of the total cost of production. There have been several attempts to reduce the cost of the production by replacing some percentage of maize with other agro-industrial by-products such as maize offal, brewers dried grain, wheat offal, cassava peel meal, brewers dried grain fortified with paim oil, rice offal etc (Ademosun, 1976; Deolanka and Singh, 1979; Ogbonna et. al., 1993; Dafwang and Shwarmen, 1996). The availability of rice bran and its lower price inform its use in poultry feeds. Rice bran is low in energy (Scott et. al., 1982), hence the need to add a high energy ingredient such as fat or oil to compensate for this. Therefore this study was carried out to investigate the performance and utilization of rice bran with or without palm oil when included in starter broilers' ration.

\section{Materials and methods}

One hundred and forty four (144) day-old broiler chicks of hubbard breed were housed in an electrically heated battery brooders and were fed diets derived from a $3 \times 2$ factorial experimental 
Table 1: $\quad$ Composition of broiler starter diets $\%$

\begin{tabular}{|c|c|c|c|c|c|c|}
\hline \multirow[b]{2}{*}{ Ingredients } & \multicolumn{4}{|c|}{ DIETS } & \multirow[b]{2}{*}{5} & \multirow{2}{*}{6} \\
\hline & 1 & 2 & 3 & 4 & & \\
\hline Maize & 50.00 & 45.00 & 40.00 & 35.00 & 30.00 & 25.00 \\
\hline Rice bran & $\cdot$ & - & 10.00 & 10.00 & 20.00 & 20.00 \\
\hline Paim oil & - & 5,00 & $\cdot$ & 5.00 & $\cdot$ & 5.00 \\
\hline Corn bran & 10.00 & 10.00 & 10.00 & 10.00 & 10.00 & 10.00 \\
\hline Soybean meal & 36.46 & 36.46 & 35.61 & 36.40 & 34,76 & 35.67 \\
\hline Bone meal & 2.41 & 2.41 & 2.41 & 2.41 & 2.41 & 2.41 \\
\hline Oyster shell & 0.46 & 0.46 & 0.46 & 0.46 & 0.46 & 0.46 \\
\hline Premix & 0.25 & 0.25 & 0.25 & 0.25 & 0.25 & 0.25 \\
\hline Salt & 0.25 & 0.25 & 0.25 & 0.25 & 0.25 & 0.25 \\
\hline Methionine & 0.10 & 0.10 & 0.10 & 0.10 & 0.10 & 0.10 \\
\hline Sand & 0.07 & 0.07 & 0.92 & 0.13 & 1.77 & 0.86 \\
\hline Total & 100.00 & 100.00 & 100.00 & 100.00 & 100.00 & 100.00 \\
\hline \multicolumn{7}{|c|}{ Analysed nutrient content $\%$} \\
\hline Dry Matter (DM) & 90,0 & 90.5 & 91.2 & 90.5 & 91.5 & 93.7 \\
\hline Crude Protein & 22.03 & 22.4 & 22.4 & 22.97 & 23.16 & 22.25 \\
\hline Crude Fat & 4.0 & 8.0 & 5.0 & 9.0 & 3.6 & 8.4 \\
\hline Crude Fibre & 6.0 & 6.0 & 10.0 & 9,0 & 11.0 & 10.0 \\
\hline \multicolumn{7}{|l|}{ Calculated M. E. } \\
\hline $\mathrm{Kcal} / \mathrm{Kg}$ & 2854.2 & 3126.7 & 2708.5 & 3200.3 & 2562.7 & 857.45 \\
\hline
\end{tabular}

design using three dietary levels of rice bran and two of palm oil, (Table 1). Rice bran was included in the diets at 0,10 and $20 \%$ with or without $5 \%$ paim oil, both at the expense of maize. The experimental diets were fed adlibitum to the three replicate cages of 8 chicks during the trial period, which lasted 5 weeks.

Feed intake and weight gain were measured on a weekly basis. A nutrient retention trial was undertaken when the chicks were two weeks old. Weighed quantities of feed were supplied and excreta sample collected over a 72 hour period using the total collection method. Also, the feed intestinal transit time (FITT) through the GIT was determined by the inclusion of $0.3 \%$ Ferric oxide as a marker. FITT was determined as the time interval between the feeding of the marked diets and the appearance of the marker in the excreta. The excreta collected were oven dried 
Table 2a: Effects of dietary levels of riec bran and palm oil on performance of broiler ehicks, (1 - 5 weeks).

\begin{tabular}{|c|c|c|c|c|c|c|}
\hline \multirow{2}{*}{\multicolumn{2}{|c|}{$\begin{array}{ll}\begin{array}{l}\text { Dietary } \\
\text { Treatments }\end{array} & \begin{array}{l}\text { Feed } \\
(2 / \mathrm{bir}\end{array} \\
\text { Level of Rice bran }\end{array}$}} & $\begin{array}{l}\text { eed Intake } \\
\text { a/bird/day) }\end{array}$ & \multirow{3}{*}{$\begin{array}{c}\begin{array}{c}\text { Weight Gain } \\
\text { (g/bird/day) }\end{array} \\
+\end{array}$} & \multirow{3}{*}{$\begin{array}{c}\text { Feed:Gain } \\
\text { ratio } \\
\\
\text {. }\end{array}$} & \multirow{3}{*}{$\begin{array}{c}\text { Mortality } \\
(\%)\end{array}$} & $\begin{array}{c}\text { Cost/Benefit } \\
\text { ratio }^{\mathrm{t}}\end{array}$ \\
\hline & & & & & & \\
\hline$(\mathbf{R B})(\%)$ & & NS & & & & \\
\hline & 0 & 38.5 & $14.75^{\circ}$ & 2.58 " & 4.2 & 102.74 \\
\hline & & & & $\cdot$ & & \\
\hline & 10 & 35.7 & $14.57^{\circ}$ & $2.47^{\prime}$ & 0.0 & 89.79 \\
\hline & 20 & 36.3 & $11.29 \mathrm{~b}$ & $3.35^{\mathrm{t}}$ & 4.2 & 114.84 \\
\hline & & & & & & + \\
\hline Palm oil (PO) & & NS & $\cdot$ & $\cdot$ & & \\
\hline & 0 & 36.2 & $12.12^{6}$ & $3.1^{b}$ & 1.4 & 110.17 \\
\hline & 5 & 37.4 & $14.95^{\circ}$ & 2.5 : & 4.2 & 95.25 \\
\hline \multirow{2}{*}{\multicolumn{2}{|c|}{$\begin{array}{l}\text { Interaction (RB X PO) } \\
\text { SED }\end{array}$}} & $\bullet$ & $\cdot$ & • & - & - \\
\hline & & 1.8 & 0.83 & 0.2 & - & - \\
\hline
\end{tabular}

26 Means followed by different superscript(s) within column are significantly different $(P<0.01)$

NS Means not signifieantly different.

$1 \quad \operatorname{Cost}(\mathrm{N})$ of fced to produce a Kilogram of broiler.

Table 2b: Details of interaction of rice bran (RB) and palm oil (PO) levels:

\begin{tabular}{|c|c|c|c|c|c|c|c|c|}
\hline \multicolumn{3}{|c|}{$\begin{array}{l}\text { On feed consumed by } \\
\text { broiler ( } g / \text { bird/day) }\end{array}$} & \multicolumn{3}{|c|}{$\begin{array}{l}\text { On weight gain of broilers at } \\
5 \text { whs (g/bird / day) }\end{array}$} & \multicolumn{3}{|c|}{$\begin{array}{c}\text { On feed to gain ratie of } \\
\text { broilers }\end{array}$} \\
\hline \multicolumn{3}{|c|}{ Level of PO(\%) } & \multicolumn{2}{|c|}{ Level of PO (\%) } & \multicolumn{4}{|c|}{ Level of $P O(\%)$} \\
\hline$\therefore$ : of RB $(\%)$ & 0 & 5 & L.evel of RE & & 5 & Level of RB ( \%) & 0 & 5 \\
\hline 9 & $39.0^{4}$ & $37.7 \mathrm{~s}$ & 0 & $14.7^{4}$ & $14.8^{*}$ & 0 & $2.6^{\circ}$ & $25^{+}$ \\
\hline 12 & $36.7^{*}$ & $34.7^{\mathrm{ks}}$ & 10 & $13.3^{\circ}$ & $15.8^{\circ}$ & 10 & $2.7 \mathrm{t}$ & $2.2^{\circ}$ \\
\hline : & $33 \sigma^{\circ}$ & 39.74 & 20 & $8.3^{4}$ & $14.3^{\text {at }}$ & 20 & $3.8^{=}$ & $2.8^{2}$ \\
\hline$\Leftrightarrow 5$ & & & SED & & & SED & 0 & \\
\hline
\end{tabular}

$\because t 3: 5$ sollowed by difterent superseript(s) within rows and column are significantly different $=55$, 
at $70^{\circ} \mathrm{C}$, weighed and ground prior to chemical analysis.

At the end of the trial period a bird was randomly selected from each replicate and slaughtered. The gizzard was removed, opened and the ingesta therein emptied and the weight taken to calculate the percentage of gizzard relative to the live weight of the bird.

\section{Chemical analysis}

Feed and excreta samples were subjected to proximate analysis using the method of $\mathrm{AOAC}$ (1980). Crude fibre was determined using the method described by Atteh (2002).

\section{Slatistical analysis}

Data collected were subjected to analysis of variance and means separated using the model for factorial design and Where significant differences were observed, means were further, subjected to least significant difference test (Steel and Torrie, 1980).

\section{Results}

Dietary levels of palm oil and rice bran had no significant effect on feed intake $(P>0.05$. Table 2a). However, there were significant interactions between dietary levels of rice bran and palm oil on feed intake, weight gain and feed/gain ratio, details of which is shown in Table $2 b$. Thus in the absence of palm oil, increase in dietary level of rice bran caused a decrease in feed intake while the reverse was the case in the presence of paim oil $(P<0,05)$. Although dietary palm oil bad no significant effect on weight gain in the absence of rice bran, there was improved weight gain both at 10 and $20 \%$ dietary level of rice bran with addition of palm oil ( $\mathrm{P}<0.05)$. Addition of $5 \%$ palm oil to the diet, irrespective of dietary level

Table 3: Effects of Dietary levels of Rice bran and paim oil on apparent nutrient retention, Feed Intestinal transit time (FTTT) and gizard weight

\begin{tabular}{clllcc}
\hline Dietary treatments & $\begin{array}{l}\text { Crude } \\
\text { Protein (\%) }\end{array}$ & $\begin{array}{l}\text { Crude } \\
\text { Fat (\%) }\end{array}$ & $\begin{array}{l}\text { Crude } \\
\text { Fibre (\%) }\end{array}$ & $\begin{array}{c}\text { FITT } \\
\text { (Hrs) }\end{array}$ & $\begin{array}{c}\text { Gizzard } \\
\text { Weight }(\%)^{\prime}\end{array}$ \\
\hline Level of Rice bran(\%) & $*$ & NS & NS & $*$ & $*$ \\
0 & $63.9^{*}$ & 66.88 & 41.00 & $2.39^{*}$ & $2.96^{\circ}$ \\
10 & $58.4^{\circ}$ & 63.17 & 35.33 & $2.26^{\circ}$ & $3.64^{\circ}$ \\
20 & $52.43^{\circ}$ & 62.83 & 34.17 & $2.10^{\circ}$ & $4.24^{*}$ \\
Level of Palm oil (\%) & 4 & NS & NS & $*$ & $*$ \\
0 & $53.96^{\circ}$ & 60.53 & 32.78 & $2.19^{\circ}$ & $4.01^{*}$ \\
5 & $62.82^{*}$ & 68.07 & 40.89 & $2.3^{*}$ & $3.22^{\circ}$ \\
Interaction (RBXPO) & NS & NS & NS & NS & NS \\
SED & 3.42 & 6.94 & 9.82 & 0.07 & 0.23 \\
\hline
\end{tabular}

ah $\mathrm{e}$ Means followed by different superseript(s) within column are significantly different $(\mathrm{P}<0.01)$

NS For means not significantly different

1 Percentage of gizzard relative to body weight. 
Table 4:

Cost to benefit analysis of broiler starter

\begin{tabular}{lllllll}
\hline DIETS & 1 & 2 & 3 & 4 & 5 & 6 \\
\hline Cost/Kg of diet (N) & 38.45 & 41.20 & 35.54 & 37.17 & 32.63 & 35.93 \\
Cost reduced relative to control diet $1(\%)$ & - & -7.15 & 7.57 & 3.45 & 15.14 & 6.57 \\
Cost of producing $1 \mathrm{Kg}$ of broiler $(\mathrm{N} / \mathrm{Kg})$ & 99.97 & 103.0 & 95.96 & 81.77 & 123.99 & 00.60 \\
Maize replaced $(\%)$ & - & 5 & 10 & 15 & 20 & 25 \\
\hline
\end{tabular}

of rice bran caused a reduction in feed to gain ratio $(P<0.05)$. Birds fed diet with $10 \%$ rice bran and $5 \%$ palm oil had comparable feed/gain ratio with diets without rice bran.

Increase in dietary levels of rice bran cause a significant $(P<0.05)$ reduction in crude protein (CP) retention (Table 3 ) while palm oil addition resulted in significant increase in $C P$ retained $(P<0.05)$. There was no significant interaction between dietary rice bran and palm oil on protein retention. There was no significant effect of dietary levels of rice bran or palm oil on fat and crude fibre retention $(P<0.05)$. The crude fibre retained decreased as the rice bran level of inclusion increased. No significant interaction between dietary rice bran and palm oil was observed $(P>0.05)$ on these parameters.

There was a decrease in FITT with increase in dietary level of rice bran $(\mathrm{P}<0.05)$ (Table 3 ). Addition of palm oil increased FITT $(\mathrm{P}<0.05)$. However there was no significant interaction on this parameter.

Gizzard weight increased $(P<0.05)$ with increased level of rice bran while addition of fat caused a reduction in gizzard weight $(P<0.05)$. There was no significant interaction between dietary level of rice bran and palm oil on gizzard weight $(P>0.05)$. Cost to benefit ratio analysis showed that the diet with $20 \%$ level of rice bran was cheaper in terms of feed cost with a resultant higher cost of producing one kilogram of broiler (Table $2 \mathrm{a}$ and 4), due to the need to eat more quantity of the feed to gain a kilogram weight.

\section{Discussion}

There was significant interaction between dietary levels of rice bran and palm oil on feed intake, indicating that the feed intake response of starting broilers to dietary rice bran depended on the presence or absence of supplementary fat. The energy content of the diet does not seem to be the factor that determines feed intake in this trial. Thus feed intake reduced with increase in dietary level of rice bran in the absence of palm oil despite the associated reduction in energy intake. Addition of $5 \%$ palm oil to the diet with $20 \%$ rice bran improved feed intake suggesting that energy was not the reason for the trend of feed intake observed. The reduced trend in feed intake observed is thought to be related to a combination of palatability and bulkiness of rice bran which affects gut-fill but fat is not bulky hence it has opposite effect viz improving palatability (Dale and Fuller, 1978) and reduce dustiness of feed (Summer's and Lesson, 1976) as observed in this trial. There was the tendency for supplemental palm oil to improve weight gain and feed efficiency supporting earlier reports of Waldroup et.al, (1976), Dale and Fuller (1979) and Coon et.al., (1981). The improvement in weight gain of the birds fed diets with supplemental palm 
oil relative to those without could be attributed to the extra caloric effect of fat accompanied with a reduced feed passage time in the GIT. This would allow increased utilization of other constituents of the diets similar to that reported by Matoes and Sell, (1980), (1981 a, b) and Lessire et. al., (1982).

Dietary levels of rice bran and paim oil affected feed/gain ratio. Birds fed diets with $10 \%$ rice bran and $5 \%$ palm oil had almost simitar utilization with those fed the control. Generally, the feed/ gain ratio improved with palm oil inclusion. This observation which supports the reports of Waldroup et. al., (1976) and Griffith et. al., (1977) that feed/gain ratio is improved with supplemental fat. The observed increase in feed intestinal transit time due to palm oil inclusion which was greatest in birds fed diet with $10 \%$ rice bran fortified with $5 \%$ palm oil confirms the earlier reports of Horani and Sell (1977) and Matoes and Sell $(1980,1981 \mathrm{~b})$. The decrease effect on feed passage time caused by rice bran was greatest in the $20 \%$ level due to gut-fill and bulkiness of the feed, which affected the emptying tendency of the GIT.

Results of this trial showed that broiler chicks could tolerate up to $10 \%$ rice bran if fed along with $5 \%$ fat. This combination was an economical substitute for $15 \%$ maize. It was observed in this study that with respect to weight gain and feed efficiency, significant interaction existed between dietary palm oil and rice bran when used in broiler starter formulations. The mode of action of the effects of those two ingredients is associated with their opposite effects on feed intestinal transit time in the GIT.

The cost to benefit ratio showed that it is cheaper to produce one kilogram of broiler by using 10\% rice bran with $5 \%$ palm oil. Although $20 \%$ inclusion level was least expensive in terms of feed cost, however, it cost more to produce one kilogram of broiler. This is because of the need to eat more of the diet by the birds to gain one kilogram weight.

\section{Conclusion}

Judging from the percentage maize replaced, feed cost reduction and cost/benefit ratio, $10 \%$ rice bran with palm oil is considered optimum for broiler chicks. $20 \%$ dietary rice bran without supplemental oil was detrimental to the performance of the broilers.

It is recommended that when maize is expensive, the abundant rice bran with palm oil should be exploited for use.

\section{References}

Ademosun, A. A., (1976). Livestock production in Nigeria. Our commissions and Omission. Inaugural Lecture Serics. 17 University of Ife, Nigeria.

Association of Official Analytical Chemists (A.O.A.C) (1980). 13th Edition, A.O.A.C., Washington DC. Pg 21,447 .

Atteh, J. O. (2002). Principles and practice of livestock feed manufacturing. Adlek Printers, Ilorin. pp 137.

Carew, L. B., Machemer, R. H., Sharp R. W. and Foss, D. C., (1972). Fat absorption by the very young chick. Poult. Sci., $51: 738-742$.

Coon, C. N., Becker, W. A. and Spencer, J. V. (1981). The effect of feeding high energy diets containing supplemental fat on broiler weight gain, feed efficiency and carcass composition. Poult Sci., 60:1264 - 1271 . 
Dafwang, I. I and Shwarmen E. B. N. (1996). Utilization of rice offal in practical rations for broiler chicks Nig. $J$ Anim.Prod. (23):21-23.

Dale, N. M. and Fuller, H. L. (1978). The effect of dietary fat in free choice selection of d $i$ e Rouls Scis $57 \mathrm{~d} 100$.

Dale, N. M and Fuller, H. L., (1979). Effects of dict composition on feed intake and growth of chicks under stress. 1. Dietary fat levels. Poult. Sci, 58:1529 - 1534 .

Deolanker, R. P. and Singh, K. S., (1979). Trypsin inhibitor, mineral availability and performance of broiler chickens fed on diets based on rice bran. Anim. Feed Sci. and Tech (4):133-141.

\section{Griffiths, L; S. Leeson and J. D. Summers} (1977). Influence of energy system and level of various fat cources on performance and carcass composition of broilers, Poult. Sct., 56:1018 - 1026.

i. ani, F. and J. L. Sell (1977). Effect of feed grade animal fat on laying hen performance and on metabolizable energy of rations. Poult. Sci. 56:1972 $-1980$.

-ssire, M., B. Leclereq and L. Conan (1982). Metabolizable energy value of fats in chickens and adult cockerels. Anim. Feed Sci and Tech., 7:365-374.

Unoes, G. G, and J. L. Sell (1980). Influence of fat on energy utilization from selected varbohydrates. Poult. Sci, 59:1635.
Matoes, G. G. and J. L. Sell (1981a). Nature of extra metabolic effect of supplemental fat used in semi purified diets for laying hens. Poult Sci, 60:1925 - 1930.

Matoes, G. G. and J. L. Sell (1981b). Influence of fat and carbohydrate source on rate of food passage of semi purified diet for laying hens. Poult. Sci., 60:2114-2119.

Ogbonna, J. U., E. A. Adebowale, O. O. Tewe and O. G. Longe (1993), Replacing maize and wheat offal in dict of cockerels with sun dried cassava peel meal. Effect on the digestibility of cell wall constituents. Nig. J. Anim. Prod. 20:111 - 121 .

Scott, M. L., M. C., Nsheim and R. L. Young (1982). Nutrition of the chicken $3^{n} \mathrm{Ed}$. M. L. Scott and associates, Ithaca, N. Y. $\mathrm{Pg}, 86,288$.

Steel, R. G. D. and J. H. Torric (1980). Principles and procedures of statistics. Mc Graw Hill Book Co. In., New York.

Waldrop, P.W., R. J. Mitehel, J. R. Payne and Z. B. Johson (1976). Charaterization of the response of broiler chickens to diets varying in Nutrient density content. Poult, Sci., 55:130-145.

(Recelved 22 March 2003, Accepted 31 March 2009) 